\title{
New product development projects prioritization with Analytic Hierarchy Process in an automotive company
}

\author{
Valério Antonio Pamplona Salomon ${ }^{a}$ Sandra Miranda Neves ${ }^{b}$, Jefferson Olegário de Paula \\ Marcos Rolando Piccillib, Carlos Eduardo Sanches da Silva ${ }^{b}$ \\ "São Paulo State University \\ bFederal University of Itajuba
}

e-mails: salomon@feg.unesp.br; sandraneves@unifei.edu.br; jeffersonolegario@uol.com.br; marcos.piccill@br.mahle.com; sanches@unifei.edu.br

\begin{abstract}
This work presents results from a research developed in a multinational automotive company. The main objective of this research was to prioritize New Product Development (NPD) projects. NPD projects prioritization is a Multiple Criteria Decision Making (MCDM) problem. Analytic Hierarchy Process was applied to solve this decision-making problem. Mathematical Modeling, a research method of qualitative strategy was initially adopted. However, a mixed strategy was followed, as concepts of Case Study were included in the research. Therefore, that research did not the purpose to be exhaustive, that is, initially, one of research objectives was to model, with MCDM, a real case of NPD projects prioritization. Nevertheless, the decision-making model and results presented in this work can be considered by other companies, mainly from automotive sector.
\end{abstract}

Keywords: Analytic Hierarchy Process, automotive industry, Multiple Criteria Decision Making, new product development.

\section{Introduction}

The importance of New Product Development (NPD) has been significantly increased in the last years. Archer and Ghasemzadeh (1999) emphasized that there are usually more projects available for selection than can be undertaken within the physical and financial constraints of a firm. According to Cooper, Edgett and Kleinschmidt (2000), there are two ways for a business to succeed at NPD: doing projects right, or doing the right projects. Most of project management prescriptions follow the first way, what they call an "elusive goal". De Reyck et al. (2005) highlighted that the prioritization, alignment and selection of projects to compose a company's portfolio should ensure that all the areas of the organization's strategy are properly addressed.

This works presents results from a research developed in a multinational automotive company. Prioritize NPD projects was the main objective of the research. As presented in section 2, NPD projects prioritization is a Multiple Criteria Decision Making (MCDM) problem. Mathematical Modeling (ARIS, 1995), a research method of quantitative strategy, was initially adopted. However, a mixed quantitative-qualitative strategy (BRYMAN; BELL, 2007) was followed, since concepts of Case Study were included in the research.

Section 2 presents a Theoretical Background, including some concepts regarding NPD and MCDM. As presented in section 3, Analytic Hierarchy Process (AHP) was the MCDM method applied for NPD projects prioritization. In section 4 concluding remarks are presented.

\section{Theoretical background}

\subsection{New product development projects}

New products are resulted from projects performed by a firm aiming competitive advantage. The main requirement to assure this advantage is the development of a product which features satisfy customers' needs and expectations. NPD implies to the organization in the innovation promoting and Research \& Development (R\&D) investing to create radically new concepts. This is as a key requirement for business success (CHAPMAN; HYLAND, 2004). Firms that consistently define, resource and execute NPD projects significantly more effectively and efficiently than their competitors are rewarded by significant strategic advantage (WHEELWRIGHT; CLARK, 1994).

A project portfolio is a group of projects that are carried out under the sponsorship or management of a particular organization (ARCHER; GHASEMZADEH, 1999). NPD prioritization is a stage of Project Portfolio Management. This stage enhances company to concentrate in fewer 
but more worthwhile projects (COOPER; EDGETT; KLEINSCHMIDT, 2001). In Project Portfolio Management, projects are often scored according to financial indicators, success probability, and alignment with business's objectives. These scores are provided by experts, but, some difficulties were often faced, as, for instance, conflicting criteria consideration, uncertainty or risk in the available data, and a great number of feasible projects to prioritize.

From the exposed in this section, it can be perceived that NPD projects prioritization is a Multi-Criteria Decision Making (MCDM) problem. This fact suggests the use of an MCDM method. The AHP (SAATY, 2010a) was the chosen method, as argued and presented in section 3. Reasons of the choice for AHP include the availability of a web-software to its application. The use of this platform facilitated the group decision making process.

\subsection{Analytic Hierarchy Process}

A fundamental aspect of the AHP is making paired comparisons of homogeneous activities or items (SAATY, 2010b). This aspect implies in the first limitation of AHP to solve the NPD projects prioritization problem. That is, the NPD projects have to be homogenous. If there are one or more projects clearly better than other projects, according to diverse and important criteria, the AHP may not be directly applied. The sets of projects must be divided in two or more sets, and then, the AHP could be used to prioritize the projects inside the sets.

Independency among the NPD projects is other limitation of AHP application. That is, the choice for a project must not cause any impact in the choice for another project. If some dependency, or influence, between two or more projects were identified, then another MCDM method, the Analytic Network Process (ANP) may be more appropriated to solve that problem. These two conditions for AHP application can be verified in NPD projects prioritization presented in section 3 .

Another interesting aspect for AHP application is the pairwise comparisons number. The AHP application considering nine criteria and five alternatives will need 190 comparisons. A comparisons matrix needs $n(n-1) / 2$ comparisons to be fully completed (SAATY, 2001). Incomplete Pairwise Comparisons (IPC) is an algorithm developed to reduce the comparisons number, allowing the group to focus on discussion rather than the laborious task of complete, in full, each comparisons matrix (HARKER, 1987). After $n$ comparisons, the algorithm indicates what should be the next one. Or else, the decision maker is informed that the non provided comparisons will no longer change the priorities. IPC calculations are based in the graph-theoretic structure of the pairwise comparisons matrix and the gradient of its Right Eigenvector. So, this algorithm is too difficult to be performed only with a piece of paper and a calculator in hand. But, it can be implemented in spreadsheets.

Despites its limitations, from the middle of the 1980s, AHP is the MCDM method with the highest number of scientific publications (WALLENIUS et al., 2008). As major part of those works reports case studies, possibly, AHP has more real world applications than any other MCDM method. But, IPC was not widely applied as AHP. One reason may be the fact that, unlike AHP, there is no very well know software that facilitates IPC implementation. Usually, academic or commercial AHP software deals with the main principle of IPC: the reduction on the number of comparisons. That is, the software provides priorities for matrices with $(n-1)$ comparisons. But, there is no AHP software that performs IPC's next steps: to indicate if the comparisons could stop, or else, to indicate what comparison should be the next one.

A difficulty in group decision making is that the decision makers are frequently reluctant to reveal their true opinions (CONDON; GOLDEN; WASIL, 2003). So, commercial versions of AHP software can be applied with special hardware. The hardware allows some secret to group members, since they can make their comparisons and other members do not instantly know them, as it happens in an open session. But, the use of hardware has two disadvantages: the first one is the cost. The second disadvantage of using hardware is the need of putting all group members in a room to get simultaneous comparisons. This way, new versions of AHP software were developed aiming the use of Internet to reduce these disadvantages. These are the web-based versions of AHP software.

There are several possibilities to aggregate the pairwise comparisons individually provided by a group. One is aggregating each comparison provided by the group member into aggregated comparisons matrices. Another possibility is aggregating the overall priorities of the alternatives from each group member into an aggregated vector of priorities. The first procedure is the indicated one when the group members

[...] are willing to, or must relinquish their own preferences (values or objectives) for the good of the organization. They act in concert and put their judgments in such a way that the group becomes a new individual [...] (FORMAN; PENIWATI, 1998, p. 166).

This procedure is commonly referred as Aggregation of Individual Judgments (AIJ).

In section 3, it is presented the AHP application to NPD projects prioritization. It was planned to use group decision making and IPC concepts. A version of AHP webbased software was applied. 


\section{AHP application}

These work reports results from a research developed at an automotive production plant located in Brazil. This plant is one of 115 units of a multinational group, spread on four continents, with headquarter in Germany. The group employs more than 40,000 people and, recently, has achieved annual sales around 5 billion Euros. One of the 30 largest automotive suppliers worldwide, the group is a top manufacturer of components and systems for combustion engines.

As in April 2010, the group has nine units in South America: five production plants located in the Brazilian states of Minas Gerais, Rio de Janeiro, and São Paulo. There is also an R\&D Center and a Distribution Center in Brazil. The other two South-American units are located in Argentina. At that time, the group was considering the development of a new product for its major plant of piston rings, located in Minas Gerais (MG Plant). Projects 1 to 6, as presented in Table 1, were NPD projects for piston rings. Moreover, the available resources to create, develop, test and launch new products, are limited by financial conditions, economy plans and market strategy.

According to procedures for the whole group, $R \& D$ projects must be analyzed on seven criteria: Budget (amount of money to be expended within the project), Sales Potential (based on volume and price, for the next 5 years), Market Trend (based on automotive industry trends, customer voice surveys, and government policies), Competitive Advantage (compared to benchmark competitors), Technical Success (possibility of the project result in a good product), Commercial Success (possibility of the new product to be sold with profit), Risk (degree of difficulty for a well succeed product development).

Three company managers of MG Plant were considered as experts to provide these comparisons. Expert 1 was the MG Plant's Quality Manager. He has worked for the group for twenty years, all of them in the MG Plant. Expert 2 was a Senior Process Engineer. At his daily work, he was directly involved with production teams. He has worked in the MG Plant since 2005. Expert 3 was the Methods and Process Engineering Chief for MG Plant. He has worked for the group for 11 years, six of them in MG Plant. Expert 3 was responsible for planning and implementation of several R\&D projects. All experts had basic knowledge in AHP, previously acquired in MBA courses. Besides the daily work of three experts was based in MG Plant, two of them were involved with business trips, at the time. So, a web-based version of AHP software was considered as a suitable tool to facilitate the pairwise comparisons collection from the experts.

Figure 1 presents the hierarchical structure for the NPD projects prioritization. With seven criteria and six alternatives, 126 pairwise comparisons would be necessary to fulfilled eight matrices, from every expert.

An academic version of web-based AHP software was used to make the data collection and processing. So, one of the co-authors of these work create an online file, in this platform. After she input the hierarchical structure in the software, the experts were defined as evaluators. Then, each expert received a message by e-mail with short instructions on how to access and input their opinions in the website. The experts were also personally contacted and informed on the research's objectives.

As commented in section 2, this version of AHP software deals with the main principle of IPC: the reduction on the number of comparisons. By default, this software only asks the comparisons from two diagonals above the main diagonal of a comparisons matrix, as presented in Table 2.

It can be observed that for the 7 criteria it would be necessary 21 comparisons. But, the software only asked 11 comparisons. For the whole hierarchy only 74 comparisons were made by every expert.

Tables 3 to 5 present the comparisons among the criteria, provided by Experts 1 to 3, respectively. The experts were

Table 1. NPD projects for piston rings.

\begin{tabular}{|c|l|l|}
\hline Project & \multicolumn{1}{|c|}{ Name } & \multicolumn{1}{|c|}{ Description } \\
\hline 1 & Turbo charger ring & $\begin{array}{l}\text { Alloy rings with high resistance to heat. } \\
\text { To be used in turbo charger sealing. }\end{array}$ \\
\hline 2 & Oil-control ring taper scraper & $\begin{array}{l}\text { Angled contact surface. } \\
\text { To reduce friction and improve oil scraping }\end{array}$ \\
\hline 3 & Scraper compression ring with low width & $\begin{array}{l}\text { Steel ring manufactured with 1.0 mm height. } \\
\text { To modern engines of low friction and high resistance. }\end{array}$ \\
\hline 4 & I-shape steel ring covered by PVD & $\begin{array}{l}\text { Steel ring with I-shape covered with Chromium Nitride applied by PVD. } \\
\text { To be used as oil ring. }\end{array}$ \\
\hline 5 & Compression ring with duplex Chrome coat & $\begin{array}{l}\text { Cast iron rings with double covering of Chromium Nitride. } \\
\text { To high resistance and medium cost. }\end{array}$ \\
\hline 6 & High performance rings covered with DLC & $\begin{array}{l}\text { Steel rings with Diamond-like Carbon coat. } \\
\text { To reduce friction. }\end{array}$ \\
\hline
\end{tabular}




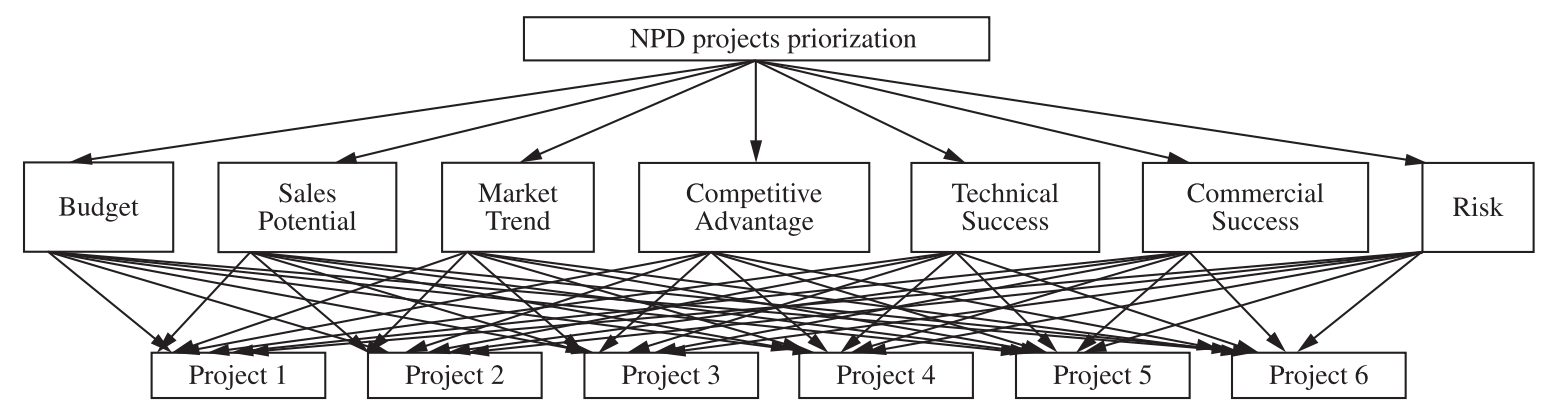

Figure 1. Hierarchical structure for the NPD projects prioritization.

Table 2. Order of collect the comparisons from experts.

\begin{tabular}{|l|c|c|c|c|c|c|c|}
\hline & C1 & C2 & C3 & C4 & C5 & C6 & C7 \\
\hline Budget (C1) & 1 & $1^{\text {st }}$ & $7^{\text {th }}$ & - & - & - & - \\
\hline Sales potential (C2) & - & 1 & $2^{\text {nd }}$ & $8^{\text {th }}$ & - & - & - \\
\hline Market trend (C3) & - & - & 1 & $3^{\text {rd }}$ & $9^{\text {th }}$ & - & - \\
\hline Competitive advantage (C4) & - & - & - & 1 & $4^{\text {th }}$ & $10^{\text {th }}$ & - \\
\hline Technical success (C5) & - & - & - & - & 1 & $5^{\text {th }}$ & $11^{\text {th }}$ \\
\hline Commercial success (C6) & - & - & - & - & - & 1 & $6^{\text {th }}$ \\
\hline Risk (C7) & - & - & - & - & - & - & 1 \\
\hline
\end{tabular}

Table 3. Comparisons from Expert 1 on the criteria to prioritize NPD projects.

\begin{tabular}{|l|c|c|c|c|c|c|c|c|}
\hline & C1 & C2 & C3 & C4 & C5 & C6 & C7 & Weight (\%) \\
\hline Budget (C1) & 1 & $1 / 8$ & $1 / 8$ & - & - & - & - & 2 \\
\hline Sales potential (C2) & - & 1 & $1 / 2$ & $1 / 2$ & - & - & - & 14 \\
\hline Market trend (C3) & - & - & 1 & $1 / 2$ & 3 & - & - & 24 \\
\hline Competitive advantage (C4) & - & - & - & 1 & 4 & 2 & - & 35 \\
\hline Technical success (C5) & - & - & - & - & 1 & 3 & 5 & 13 \\
\hline Commercial success (C6) & - & - & - & - & - & 1 & 5 & 10 \\
\hline Risk (C7) & - & - & - & - & - & - & 1 & 2 \\
\hline
\end{tabular}

Table 4. Comparisons from Expert 2 on the criteria to prioritize NPD projects.

\begin{tabular}{|l|c|c|c|c|c|c|c|c|}
\hline & C1 & C2 & C3 & C4 & C5 & C6 & C7 & Weight (\%) \\
\hline Budget (C1) & 1 & $1 / 5$ & $1 / 3$ & - & - & - & - & 2 \\
\hline Sales potential (C2) & - & 1 & 4 & 1 & - & - & - & 18 \\
\hline Market trend (C3) & - & - & 1 & $1 / 5$ & $1 / 3$ & - & - & 5 \\
\hline Competitive advantage (C4) & - & - & - & 1 & 4 & 4 & - & 25 \\
\hline Technical success (C5) & - & - & - & - & 1 & 4 & $1 / 4$ & 11 \\
\hline Commercial success (C6) & - & - & - & - & - & 1 & 7 & 4 \\
\hline Risk (C7) & - & - & - & - & - & - & 1 & 35 \\
\hline
\end{tabular}

considered as equally important. That is, the comparisons had the same weight when aggregated. The whole data collection spends less than one month.

Table 6 presents the vectors of overall priorities obtained from the comparisons provided by the experts. This table also presents two other vectors: the one obtained with AIJ (provided by the software) and another obtained with the arithmetical mean of individual priorities. It can be seen, in this case, that Project 2 would be the Priority 1 project, no matter the aggregation way was the followed one.

The software provided additional analysis, as the Sensitivity Analysis or the Concordance Degree on the input data. But, the experts, and this work's co-authors, including two workers on the MG Plant, were very satisfied with the 
Table 5. Comparisons from Expert 3 on the criteria to prioritize NPD projects.

\begin{tabular}{|l|c|c|c|c|c|c|c|c|}
\hline & C1 & C2 & C3 & C4 & C5 & C6 & C7 & Weight (\%) \\
\hline Budget (C1) & 1 & $1 / 6$ & 7 & - & - & - & - & 11 \\
\hline Sales potential (C2) & - & 1 & 6 & 6 & - & - & - & 27 \\
\hline Market trend (C3) & - & - & 1 & 4 & $1 / 6$ & - & - & 6 \\
\hline Competitive advantage (C4) & - & - & - & 1 & 7 & $1 / 6$ & - & 9 \\
\hline Technical success (C5) & - & - & - & - & 1 & $1 / 7$ & $1 / 6$ & 7 \\
\hline Commercial success (C6) & - & - & - & - & - & 1 & 7 & 30 \\
\hline Risk (C7) & - & - & - & - & - & - & 1 & 10 \\
\hline
\end{tabular}

Table 6. Vectors of overall priorities.

\begin{tabular}{|c|c|c|c|c|c|}
\hline & Expert 1 (\%) & Expert 2 (\%) & Expert 3 (\%) & AIJ (\%) & AMP (\%) \\
\hline Project 1 & 23 & 14 & 16 & 16 & 18 \\
\hline Project 2 & 17 & 23 & 22 & 20 & 21 \\
\hline Project 3 & 12 & 18 & 16 & 16 & 15 \\
\hline Project 4 & 19 & 18 & 14 & 16 & 17 \\
\hline Project 5 & 15 & 11 & 17 & 15 & 14 \\
\hline Project 6 & 14 & 16 & 15 & 17 & 15 \\
\hline
\end{tabular}

AIJ = Aggregation of Individual Judgments, AMP = Arithmetical Mean of Priorities.

prioritization. Few months after the AHP application, one of the co-authors was already working with Project 2 at company's R\&D Center.

\section{Conclusions}

This work presented a group decision making in the prioritization of NPD projects in a multinational automotive company. A web-based version of AHP software was used. This software aids the efficiency and effectiveness of AHP application. That is, reducing the number of pairwise comparisons from 126 to 74, was an important factor to obtain confident data, in only one month. More important than that, the results from data processed with AHP theory was validated by the company.

The use of only three experts was not a software limitation. They were considered as the most important people to be heard, at that moment. The criteria used in the MCDM were provided by an internal procedure by the automotive company. Meanwhile, these criteria can be adopted for the prioritization of NPD projects by diverse companies.

The academic version of web based AHP software shows as a very useful tool. That is, it was well succeeded for the research proposal reposted in this work. This way, company considers acquiring a commercial license of the software. But, this decision must be subjected to future work.

\section{Acknowledgement}

The academic version of the web based AHP software was acquired with financial support from Brazilian Council of Scientific and Technological Development, (Grant
Number: CNPQ 483583/2009-0). Thanks to FAPEMIG (Process PPM-00586) and especially all interviewees.

\section{References}

ARCHER, N. P.; GHASEMZADEH, F. Anintegrated framework for project portfolio selection. International Journal of Project Management, v. 17, p. 207-216, 1999. http://dx.doi.org/10.1016/S0263-7863(98)00032-5

ARIS, R. Mathematical Modelling Techniques. New York: Dover, 1995.

BRYMAN, A.; BELL, E. Business research methods. Oxford: Oxford University, 2007.

CHAPMAN, R.; HYLAND, P. Complexity and learning behaviors in product innovation. Technovation, v. 24, p. 553-561, 2004. http://dx.doi.org/10.1016/S01664972(02)00121-9

CONDON, E.; GOLDEN, B.; WASIL, E. Visualizing group decisions in the Analytic Hierarchy Process. Computers \& Operations Research, v. 30, p. 1435-1445, 2003. http://dx.doi.org/10.1016/S0305-0548(02)00185-5

COOPER, R. G.; EDGETT, S.; KLEINSCHMIDT, E. Portfolio management for new product development: results of an industry practices study. R \& D Management, v. 31, p. 361-380, 2000. http://dx.doi.org/10.1111/14679310.00225

COOPER, R. G.; EDGETT, S. J.; KLEINSCHMIDT, E. J. New problems, new solutions: making portfolio management more effective. Research Technology Management, v. 43, p. 18-33, 2001. 
DEREYCK, B. et al. The impact of project portfolio management oninformation technology projects. International Journal of Project Management, v. 23, p. 524-537, 2005. http://dx.doi.org/10.1016/j.ijproman.2005.02.003

FORMAN, E.; PENIWATI, K. Aggregating individual judgments into priorities with the Analytic Hierarchy Process. European Journal of Operational Research, v. 108, p.165-169, 1998. http://dx.doi.org/10.1016/S03772217(97)00244-0

HARKER, P. T. Incomplete Pairwise Comparisons in the Analytic Hierarchy Process. Mathematical Modeling, v. 9, p. 837-848. 1987. http://dx.doi.org/10.1016/02700255(87)90503-3

SAATY, T. L. Decision Making with Dependence and Feedback: theAnalytic Network Process. Pittsburgh: RWS Publications, 2001.
SAATY T. L. Principia Mathematica Decernendi. Pittsburgh: RWS Publications, 2010a.

SAATY T. L. Who wonthe Winter 2010 Olympics? A quest into priorities and rankings. Journal of Multi-Criteria Decision Analysis, v. 17, n. 1-2, p. 25-36, 2010 b. http://dx.doi.org/10.1002/mcda.451

WALLENIUS, J. et al. Multiple criteria decision making, multi attribute utility theory: recent accomplishments and what lies ahead. Management Science, v. 7, p. 1336-1349, 2008. http://dx.doi.org/10.1287/mnsc.1070.0838

WHEELWRIGHT, S. C.; CLARK, K. B. Accelerating the design-build-testcycle for effective product development. International Marketing Review, v. 11, p. 32-46, 1994. http://dx.doi.org/10.1108/02651339410057509 